\title{
A Study on Various Parameters of Personality among Monozygotic Twins
}

\author{
Poonam Rani* and Bimla Dhanda \\ Department of Human Development and Family Studies, I.C. College of Home Science, \\ CCSHAU, Hisar, Haryana - 125004, India \\ *Corresponding author
}

\section{A B S T R A C T}

\begin{tabular}{|l|}
\hline Ke y w o r d s \\
Identical, Genetic, \\
$\begin{array}{l}\text { Personality, Agreeableness, } \\
\text { Extraversion, } \\
\text { Conscientiousness openness }\end{array}$ \\
\hline Article Info \\
\hline $\begin{array}{l}\text { Accepted: } \\
\text { 08 August } 2018 \\
\text { Available Online: } \\
\text { 10 September } 2018\end{array}$ \\
\hline
\end{tabular}

Identical (monozygotic) twins have essentially the same set of genes. Identical twins are more similar than fraternal twins on a range of personality measures, indicating that characteristics are heritable. Personality and specific genes responsible for the ubiquitous heritability of personality traits has increasingly become a target for genetic research. The study was conducted in five cultural zones of Haryana state namely Khadar, Bagar, Nardak, Mewat and Ahirwal. A total number of district depending upon the availability of the twins were identified from five cultural zones of the state. A sample of 90 a pair of twins in the age group of 3 identified from different villages was assessed. Personality of twins was taken as dependent variable. A Five Factor Personality Questionnaire for preschool children was used for assessing the personality traits of preschool twins (Cathy L. Grist (revised), 2011). Result revealed that the various parameters namely agreeableness, neuroticism, extraversion, conscientiousness and openness revealed that the overall personality (0.60) was not significantly differences among monozygotic twins.

\section{Introduction}

Identical and fraternal twins hold the keys to give understanding on personality traits. Identical (monozygotic) twins have essentially the same set of genes, while fraternal (or dizygotic) twins have, on average, a halfidentical set. The idea is that if the twins are raised in the same household, then the twins will be influenced by their environments to an equal degree, and this influence will be pretty much equal for identical and fraternal twins. Studies have found that identical twins are more similar than fraternal twins on a range of personality measures, indicating that characteristics are heritable. Personality and specific genes responsible for the ubiquitous heritability of personality traits has increasingly become a target for genetic research (Benjamin et al., 2002).

Personality traits are defined as the relatively enduring patterns of thoughts, feelings, and behaviors that differentiate individuals from one another and are elicited in trait affording situations (Roberts, 2009). Personality increasing at all ages, but the rate of increase was greater at younger ages than at older ages. The first of the five factors is extraversion. Extraversion is an energetic approach toward the social and material world and includes traits such as sociability, activity, 
assertiveness, and positive emotionality. The second factor, neuroticism, concerns the ease and frequency with which a person becomes upset and distressed. Agreeableness "contrasts a prosocial and communal orientation toward others with antagonism and includes traits such as altruism, tender-mindedness, trust, and modesty. The most commonly used label for the next factor is conscientiousness, refers to "socially prescribed impulse control that facilitates task- and goal-directed behavior, such as thinking before acting, delaying gratification, following norms and rules, and planning, organizing, and prioritizing tasks. The fifth factor, most often called openness to experience involves curiosity, flexibility, imaginativeness, and willingness to immerse oneself in atypical experiences such as involvement in social experience. Freud claimed that the basic personality is set by age five.

The five-factor model of personality provides a rather static account of personality (Terracciano et al., 2006). There is no doubt that early experience influences later development but this influence could account for individual differences in many aspects such as cognition, socio- emotional skills and personality (Malekpour, 2007). Children exhibit developmental changes in traits with individual differences during the period of 2 to 8 years that are rapid and wide-ranging (Lamb et al., 2002).

\section{Objective}

To assess the various parameters of personality of monozygotic twins.

\section{Materials and Methods}

The various methodological research procedures adopted in the study have been described along with the relevant details under following subheadings:

\section{Locale of the study}

The study was conducted in five cultural zones of Haryana state namely Khadar, Bagar, Nardak, Mewat and Ahirwal. A total number of district depending upon the availability of the twins were identified from five cultural zones of the state.

\section{Selection of sample}

A sample of 90 a pair of twins in the age group of 3 identified from different villages was assessed.

\section{Variables}

Dependent variable: personality of twins.

\section{Tools}

A Five Factor Personality Questionnaire for preschool children was used for assessing the personality traits of preschool twins [Cathy L. Grist (revised), 2011].

\section{Statistical analysis}

Mean, standard deviation and ANNOVA were carried out.

\section{Results and Discussion}

This study on various parameters of personality has given us a useful set of information regarding individual differences in monozygotic twins. It is concluded that the various parameters namely agreeableness, neuroticism, conscientiousness and openness revealed that there were non-significantly differences among the monozygotic twins except the extraversion.

It shows that the overall personality was not significantly differences among monozygotic twins (Table 1). 
Table.1 Analysis of variance for various parameters among monozygotic twins

\begin{tabular}{|c|c|c|c|c|c|}
\hline & $\begin{array}{l}\text { Source of } \\
\text { variations }\end{array}$ & df & Sum of Squares & Mean of Square & F value \\
\hline \multirow[t]{4}{*}{ Agreeableness } & Twins & 89 & 2049.8 & 23.0 & \multirow[t]{4}{*}{0.06} \\
\hline & Group & 1 & 0.5 & 0.5 & \\
\hline & Error & 89 & 737.4 & 8.2 & \\
\hline & Total & 179 & 2787.8 & 23.0 & \\
\hline \multirow[t]{4}{*}{ Extraversion } & Twins & 89 & 839.2 & 9.4 & \multirow[t]{4}{*}{$3.27 *$} \\
\hline & Group & 1 & 11.8 & 11.8 & \\
\hline & Error & 89 & 319.2 & 3.6 & \\
\hline & Total & 179 & 1170.3 & 9.4 & \\
\hline \multirow[t]{4}{*}{ Neuroticism } & Twins & 89 & 765.3 & 8.6 & \multirow[t]{4}{*}{2.56} \\
\hline & Group & 1 & 13.9 & 13.9 & \\
\hline & Error & 89 & 481.1 & 5.4 & \\
\hline & Total & 179 & 1260.3 & 8.6 & \\
\hline \multirow[t]{4}{*}{ Conscientiousness } & Twins & 89 & 1509.5 & 16.9 & \multirow[t]{4}{*}{0.30} \\
\hline & Group & 1 & 2.0 & 2.0 & \\
\hline & Error & 89 & 577.5 & 6.5 & \\
\hline & Total & 179 & 2088.9 & 16.9 & \\
\hline \multirow[t]{4}{*}{ Openness } & Twins & 89 & 445.3 & 5.0 & \multirow[t]{4}{*}{0.8} \\
\hline & Group & 1 & 1.6 & 1.6 & \\
\hline & Error & 89 & 176.9 & 1.9 & \\
\hline & Total & 179 & 623.8 & 5.0 & \\
\hline \multirow{4}{*}{$\begin{array}{l}\text { Overall } \\
\text { personality }\end{array}$} & Twins & 89 & 7616.9 & 107.8 & \multirow[t]{4}{*}{0.60} \\
\hline & Group & 1 & 4.4 & 4.4 & \\
\hline & Error & 89 & 2923.3 & 7.2 & \\
\hline & Total & 179 & 10246.6 & 107.8 & \\
\hline
\end{tabular}

Foy et al., (2001) did not find any differences between MZ and DZ twins in their level of intimacy, but MZ twins were more likely to name each other as their closest friend compared to DZ twins.

Vernon et al., (2001) studied that fraternal twins, or dizygotic twins, share exactly half their genes with each other. They are not as optimal as identical twins for deciphering the degrees of genetic influence, but they are a very good basis for comparison for identical twins. Kirwan (2014) found that all of the big five personality traits were correlated significantly and positively with openness, emotional stability, agreeableness, conscientiousness, extraversion and the personality traits also correlated significantly with learner self-direction. Kaplan et al., (2012) found that there was a significant interaction between trust and openness over and above gender, such that individuals low in both trust and openness were at the greatest risk for high levels of social anxiety. There were no other interactions between trust and the other factors.

\section{References}

Benjamin, J., Ebstein, R., and Belmaker, R. H. 2002. Molecular genetics of human personality. Washington, DC: American 
Psychiatric Press. Behavioral Scientist, 44:10-31.

Foy, A. K., Vernon, P. A. and Jang, K. 2001. Examining the dimensions of intimacy in twins and peer relationships. Twin Research, 4: 443-452.

Kaplan, S. C., Levinson, C. A. and Rodebaugh, T. L. 2012. Social Anxiety and the Big Five Personality Traits: The Interactive Relationship of Trust and Openness. Washington University in St. Louis.

Kirwan, J. 2014. An Investigation of Big Five and Narrow Personality Traits in Relation to Learner Self-Direction in Undergraduate Students. Journal of Curriculum and Teaching, 3(1)74-85.

Lamb, M. E., Chuang, S. S., Wessels, H., Broberg, A. G. and Hwang, C. P. 2002. Emergence and construct validation of the Big Five factors in early childhood: a longitudinal analysis of their ontogeny in Sweden. Child Development,
73:1517-24.

Malekpour, M. 2007. Effects of attachment on early and later development. The British Journal of Developmental Disabilities, 53(105): 81-95.

Robert, P. C., Haworth, M. A. and Philip, D. 2008. A Twin Study into the Genetic and Environmental Influences on Academic Performance in Science in nine-year-old Boys and Girls. International Journal of Science Education. 30(8): 1003.

Terracciano, A., Costa, P. T. and McCrae, R. R. 2006. Personality plasticity after age 30. Personality and Social Psychology Bulletin, 32:999-1009.

Vernon, P. A., Jang, K. L., Harris, J. A. and McCarthy, J. M. 2000. Environmental predictors of personality differences: A twin and sibling study. Journal of Personality and Social Psychology, 72: 177-183.

\section{How to cite this article:}

Poonam Rani and Bimla Dhanda. 2018. A Study on Various Parameters of Personality among Monozygotic Twins. Int.J.Curr.Microbiol.App.Sci. 7(09): 1207-1210. doi: https://doi.org/10.20546/ijcmas.2018.709.143 